\title{
Environmental Monitoring and Exploratory Development of a Predictive Model for Dead Spot of Creeping Bentgrass
}

\author{
John E. Kaminski, Department of Plant Science, University of Connecticut, Storrs 06269; Peter H. Dernoeden, \\ Department of Plant Science and Landscape Architecture, University of Maryland, College Park 20742; and Michael
} A. Fidanza, Berks Campus, The Pennsylvania State University, Reading 19610

\begin{abstract}
Kaminski, J. E., Dernoeden, P. H., and Fidanza, M. A. 2007. Environmental monitoring and exploratory development of a predictive model for dead spot of creeping bentgrass. Plant Dis. 91:565-573.

Dead spot of creeping bentgrass is incited by Ophiosphaerella agrostis. The objectives of this 3year field study were to: (i) elucidate environmental conditions associated with the expression of dead spot symptoms, (ii) develop a model to assist in predicting the appearance of dead spot symptoms and epidemics in creeping bentgrass, and (iii) elucidate the association between ascospore release and the appearance of new dead spot symptoms. Environmental parameters measured included relative humidity (RH), air (AT) and soil (ST) temperatures, solar irradiance (SOL), precipitation and irrigation (RAIN), and leaf wetness duration (LWD). Dead spot symptoms generally did not occur at temperatures (air or soil) below $15^{\circ} \mathrm{C}$. Two descriptive models were developed that predicted the appearance of dead spot symptoms with an accuracy of 74 to $80 \%$. Between 1 May and 31 October 2000 to 2002, the appearance of new dead spot infection centers was most accurately predicted $(80 \%)$ by the single parameter of $\mathrm{ST}_{\text {Mean }} \geq 20^{\circ} \mathrm{C}$. In years with severe levels of dead spot, the occurrence of major infection events was predicted on 37 of 40 days $(93 \%)$. A combination of elevated air $\left(\mathrm{AT}_{\mathrm{Max}} \geq 27^{\circ} \mathrm{C}\right)$ and soil $\left(\mathrm{ST}_{\text {Mean }} \geq 18^{\circ} \mathrm{C}\right)$ temperatures, low relative humidity $\left(\mathrm{RH}_{\text {Mean }} \leq 80 \%\right.$ ), shortened periods of leaf wetness (LWD $\leq 14 \mathrm{~h}$ ), and high levels of solar radiation $\left(\mathrm{SOL}_{\text {Mean }} \geq 230 \mathrm{~W} \mathrm{~m}^{-2}\right.$ ) were associated with the development of major dead spot epidemics. Ascospore discharge and the appearance of new infection centers occurred in a cyclic pattern that peaked about every 12 days. New infection centers appeared 3 to 10 days after the release of a large number of ascospores.
\end{abstract}

Additional keywords: aerobiology, epidemiology, pseudothecia

Dead spot is incited by Ophiosphaerella agrostis Dernoeden, M.P.S. Câmara, N.R. O'Neill, van Berkum, et M.E. Palm and is a relatively new disease of creeping bentgrass (Agrostis stolonifera L.) $(1,6)$. Within 6 years of its initial discovery, the pathogen had been isolated from creeping bentgrass putting greens in at least 11 states in the United States $(6,13,14)$. Dead spot severity may vary from a few spots to several hundred per green, and depressions or pits may form in the putting surface. Infection centers may be distributed throughout the putting green or localized, but the spots generally only coalesce under high disease pressure.

On creeping bentgrass maintained as golf putting greens, dead spot symptoms appear initially as small, reddish-brown spots approximately 1.0 to $2.0 \mathrm{~cm}$ in diameter, but may increase to $8.0 \mathrm{~cm}$ in diameter $(6,14)$. As the disease progresses,

Corresponding author: J. E. Kaminski
E-mail: john.kaminski@uconn.edu

Accepted for publication 30 November 2006

doi:10.1094/PDIS-91-5-0565

(C) 2007 The American Phytopathological Society grass in the center of the spots becomes tan, while leaves in the outer edge appear reddish-brown. Numerous pseudothecia generally can be found in the absence of fungicide use on necrotic leaf, sheath, and stolon tissues. Foliar mycelium has not been observed in the field. Field observations suggest that dead spot is a polycyclic disease and that $O$. agrostis exists solely in its sexual state (1). Secondary infections during the season result from ascospores. In the field, ascospores are released in greatest numbers during dawn and dusk, and only low levels of ascospores are released during the day when the canopy is dry (18). Ascospores alighting onto bentgrass tissues can germinate in as little as 2 $h$ (19). Based on lab and field observations, ascospores often wash into the collar region of leaves, directly penetrate, and ramify downward into sheaths and eventually crowns, stolons, and roots.

Infected bentgrass recovers very slowly, as stolon growth into dead patches appears restrained or inhibited. Active disease symptoms are not observed during winter, but depressions or pits in the putting surface often remain visible until turfgrass growth resumes the following spring. Laboratory studies revealed that reactivation of dead spot may occur after 12 to 20 days incubation at a constant temperature of 25 or $30^{\circ} \mathrm{C}(19)$.

In the mid-Atlantic region of the United States, dead spot may be active in the field between May and December and typically is most severe during the summer months (14). In laboratory studies, the optimum temperatures for growth of $O$. agrostis mycelia ranged from 25 to $30^{\circ} \mathrm{C}$, and growth was suppressed at $35^{\circ} \mathrm{C}$ (19). Active dead spot infection centers generally appear in areas with full sun and good air circulation. In particular, O. agrostis infection centers may first appear along ridges and on mounds and south-facing slopes of greens (14). These areas are particularly prone to higher soil temperatures and often are the first to exhibit drought symptoms.

Weather-based prediction models have been developed for several turfgrass diseases including anthracnose (Colletotrichum graminicola (Ces.) Wils.), dollar spot (Sclerotinia homoeocarpa F.T. Bennett), Pythium blight (Pythium aphanidermatum (Edson) Fitzp.), and brown patch (Rhizoctonia solani Kühn) $(5,8,12,21)$. Little is known regarding the environmental conditions that influence the development of dead spot. This study was designed to define environmental conditions surrounding dead spot development and epidemics in creeping bentgrass. The objectives of this research therefore were to: (i) identify environmental conditions associated with the expression of dead spot symptoms, (ii) develop a model to assist in predicting the appearance of dead spot symptoms and epidemics in creeping bentgrass, and (iii) elucidate the association between ascospore release and the appearance of new dead spot symptoms.

\section{MATERIALS AND METHODS}

Environmental and disease monitoring was conducted at the University of Maryland Paint Branch Turfgrass Research Facility in College Park between 2000 and 2002. In August 1999, a research putting green was constructed to United States Golf Association (USGA) specifications (26). The soil was a modified sand mix (97\% sand, $1 \%$ silt, and $2 \%$ clay) with a $\mathrm{pH}$ of 6.9 and $10 \mathrm{mg}$ organic matter $\mathrm{g}^{-1}$ of soil. Soil P (42 to $79 \mathrm{~kg} \mathrm{ha}^{-1}$ ) and K (4 to $16 \mathrm{~kg} \mathrm{ha}^{-1}$ ) levels varied throughout the 3 years and generally were low to moderate.

Each year, field evaluations were initiated on separate sections of the same re- 
search green. On 20 September 1999, two separate areas $\left(465 \mathrm{~m}^{2}\right)$ were seeded $(50$ $\mathrm{kg}$ seed $\mathrm{ha}^{-1}$ ) with 'L-93' or 'Providence' creeping bentgrass. Due to a decline in disease intensity in 2001, a section of the putting green was vertically mowed to 1 $\mathrm{cm}$ depth, fumigated with methyl bromide ( $98 \%$ methyl bromide $+2 \%$ chloropicrin) on 23 August, and overseeded with 'L-93' creeping bentgrass on 30 August. A total of 196, 72, 196, and $172 \mathrm{~kg} \mathrm{~N} \mathrm{ha}^{-1}$ were applied in 1999, 2000, 2001, and 2002, respectively. Plots were mowed three to four times weekly to a height of 4 to $5 \mathrm{~mm}$. The area was routinely irrigated, verticalmowed, and top dressed throughout the study. In all years, various insecticides and fungicides that did not target $O$. agrostis were applied to minimize damage from other turfgrass pests (15). Each year, the study area was inoculated with various isolates of $O$. agrostis $(2000=$ OpVA-1; 2001 = OpVA-1 and OpMD-9; and $2002=$ OpVA-1 and OpOH-1) (17). Inoculum consisted of a mix of tall fescue (Festuca arundinacea Schreb.) seed and wheat (Triticum aestivum L.) bran (50:50 $\mathrm{vol} / \mathrm{vol}$ ), which was prepared as previously described (7). Approximately $0.5 \mathrm{~g}$ of the $O$. agrostis inoculum was placed below the thatch and at the soil surface on $0.9-\mathrm{m}$ (2000) or 1.5-m (2001 and 2002) centers.

Environmental monitoring. Environmental conditions were monitored between 1 May and 31 October each year. Air temperature (AT) and relative humidity $(\mathrm{RH})$ were measured with a thermistor and a Vaisala capacitive sensor (Model HMP35C, Campbell Scientific, Logan, UT), respectively, situated $30 \mathrm{~cm}$ above the turf surface. Sensors were housed in a 12plate, louvered radiation shield to protect them from sunlight and rain. Soil temperature (ST) was measured by averaging data from two thermistors (Model 107B, Campbell Scientific) placed $2.5 \mathrm{~cm}$ below the soil surface. All temperature (AT and ST) and RH instruments were programmed to measure environmental conditions at 2min intervals, and the mean, maximum (max), and minimum (min) measurements were recorded every $60 \mathrm{~min}$.

Leaf wetness duration (LWD) was estimated by two (2001 and 2002) or three (2000) electrical impedance sensors (Model 237, Campbell Scientific) placed horizontally on the turf canopy. The sensors were coated with flat-white latex paint to improve their accuracy in detecting LWD (11). The electrical resistance for the sensors at the transition between wet and dry was $150 \mathrm{kOhms}$. Sensors for LWD were programmed to record readings every $15 \mathrm{~min}$, and resistance values for each sensor were recorded as either 0 for dry or 0.25 for wet during each quarter hour.

In 2000, rainfall was determined using a rain gauge placed adjacent to the study site. Additionally, total water amounts from irrigation events were estimated based on the water output from each irrigation head per minute. For 2001 and 2002, hourly precipitation and water from irrigation were determined using a tipping rain bucket (Texas Electronics Inc., Dallas, TX) situated $30 \mathrm{~cm}$ above the turf surface. Hereafter, the term "precipitation" will be used to describe the amount of water from a combination of natural rainfall and irrigation events. Solar irradiance (SOL) and wind speed (WS) data were collected by a USDA weather station located approximately $0.3 \mathrm{~km}$ from the study site. The SOL sensor (LI200X, LI-COR, Lincoln, $\mathrm{NE}$ ) was mounted on a tripod situated $3 \mathrm{~m}$ aboveground. Wind speed measurements were recorded at the same location using a Model 5103 Wind Monitor (R.M. Young Company, Traverse City, MI).

With the exception of the SOL and WS equipment, all monitoring instruments were connected to a CR-10 datalogger (Campbell Scientific) encased in a weatherproof aluminum box and powered by a $12-\mathrm{V}$ rechargeable lead battery connected to a solar panel. All instruments were programmed to measure environmental conditions at either 2-min (AT, ST, and RH) or 15-min (LWD and SOL) intervals.

The environmental conditions evaluated provided 20 variables that were tested for use in a dead spot predictive model. The 20 environmental variables were: mean percent $\mathrm{RH}$ for the $24-\mathrm{h}\left(\mathrm{RH}_{\text {Mean }}\right)$, 48-h $\left(\mathrm{RH}_{\text {Mean }} 48\right)$, and $72-\mathrm{h}\left(\mathrm{RH}_{\text {Mean }} 72\right)$ period prior to 0800 hours; minimum daily $\mathrm{RH}$ $\left(\mathrm{RH}_{\mathrm{Min}}\right)$; hours of $\mathrm{RH} \geq 90 \%$ (RH90), $\geq 75 \%$ (RH75), or $\geq 60 \%$ (RH60); min, mean, and max AT $\left({ }^{\circ} \mathrm{C}\right)\left(\mathrm{AT}_{\mathrm{Min}}, \mathrm{AT}_{\text {Mean }}\right.$, or $\left.\mathrm{AT}_{\text {Max }}\right)$; min, mean, and $\max \mathrm{ST}\left({ }^{\circ} \mathrm{C}\right)$ $\left(\mathrm{ST}_{\text {Min }}, \mathrm{ST}_{\text {Mean }}\right.$, or $\left.\mathrm{ST}_{\text {Max }}\right)$; hours of leaf wetness (LWD); total precipitation ( $\mathrm{mm}$ ) during the 24-h (RAIN24) or 48-h (RAIN48) period prior to 0800 hours; mean and max solar radiation $\left(\mathrm{W} \mathrm{m}^{-2}\right)$ $\left(\mathrm{SOL}_{\text {Mean }}\right.$ and $\left.\mathrm{SOL}_{\mathrm{Max}}\right)$; and mean and max wind speed $\left(\mathrm{m} \mathrm{s}^{-1}\right)\left(\mathrm{WS}_{\text {Mean }}\right.$ and $\mathrm{WS}_{\mathrm{Max}}$ ). All variables were determined from hourly data collected in a $24-\mathrm{h}$ period beginning at 0800 hours. Daily averages collected prior to 0800 hours were considered to have occurred the previous day. This interval was chosen to coincide with disease incidence data collection described below.

Disease monitoring. The presence of new $O$. agrostis infection centers was monitored daily between 0700 and 0900 hours. In 2000, the number of infection centers within the study area was recorded between 30 July and 31 October. In 2001 and 2002, the number of new dead spot infection centers was recorded daily between 1 May and 31 October. To ensure that individual infection centers were not counted twice, a small dot was painted next to each dead spot. Daily infection center data were adjusted to represent the number of new $O$. agrostis infection centers per $93 \mathrm{~m}^{2}\left(\mathrm{IC}_{\text {Total }}\right)$.
Dead spot descriptive model. Descriptive information regarding the appearance of dead spot infection centers and the development of a predictive model were conducted using previously described methods $(8,21)$. Days on which new $O$. agrostis infection centers were observed $\left(\mathrm{IC}_{\text {Any }}\right)$ were converted to a binary value in which $0=$ no new infection centers and $1=$ $\geq 1$ new infection center observed. Due to variation in the number of infection centers on individual rating dates, a secondary disease variable $\left(\mathrm{IC}_{\text {Major }}\right)$ was created. The variable $\mathrm{IC}_{\text {Major }}$ also consisted of binary values in which $1=$ days in which $\geq 20$ $\mathrm{IC}_{\text {Total }}$ appeared and $0=$ days in which $<20$ $\mathrm{IC}_{\text {Total }}$ appeared.

Data for the 20 environmental variables were subjected to correlation analyses to identify any variable(s) associated with $\mathrm{IC}_{\text {Any }}, \mathrm{IC}_{\text {Major }}$, and $\mathrm{IC}_{\text {Total }}$ as well as those highly correlated with each other. The strength of association among the variables was assessed based on the computed correlation coefficients. Simple correlation coefficients also were used to determine variables with multicollinearity, which may be of concern when selecting parameters for use in the development of biological models (7). Multicollinearity (i.e., intercorrelated variables) may occur when many variables included in the model measure a similar event (such as with environmental data) (9).

Comparisons were made between values of each of the 20 environmental variables for each binary disease variable $\left(\mathrm{IC}_{\text {Any }}\right.$ and $\mathrm{IC}_{\text {Major }}$ ). These comparisons were made in an attempt to discern the specific environmental conditions that occurred on days in which $\mathrm{IC}_{\text {Any }}$ and $\mathrm{IC}_{\text {Major }}$ events occurred. Data were subjected to univariate analyses, a statistical procedure which combines frequency or binary data and descriptive statistics (4). The statistical procedure used was similar to that employed by Fidanza et al. (8) to determine the impact of environmental variables on outbreaks of brown patch; the original procedure based on Kolmogorov-Smirnov tests was described by Scherm and van Bruggen (24). A Bonferroni correction (i.e., Type I error adjustment) was used to compare the 20 variables at the $P<0.05$ level. The corrected probability value was calculated taking into account the 20 variables as follows: $(0.05 / 20)=0.0025$.

To develop an explanatory model for $\mathrm{IC}_{\text {Any }}$ and $\mathrm{IC}_{\text {Major }}$, an environmental favorability index (EFI) was developed using variables that were significantly correlated with and exhibited the strongest relationship to dead spot. The validity of the EFI was determined using chi-square $\left(\chi^{2}\right)$ analyses, which compared observed dead spot symptoms with the predicted values. The $\chi^{2}$ analysis and EFI procedure were previously used to test relationships and to develop forecasting models for other turfgrass diseases including Pythium blight 
and brown patch $(8,21)$. Chi-square analyses were performed using the FREQ procedure in SAS (23). The value of $\chi^{2}$ was calculated by the equation $\chi^{2}=\sum\left[f_{\mathrm{o}}-\right.$ $\left.f_{\mathrm{e}}\right)^{2} /\left(f_{\mathrm{e}}\right)$ ], where $f_{\mathrm{o}}$ equals the number or frequency of observed outcomes and $f_{\mathrm{e}}$ represents the expected outcomes, as expressed by a "yes" or "no" event (27). Additionally, stepwise regression analyses were performed on all environmental variables to determine if a simplified EFI model could be developed that would accurately predict dead spot epidemics using the REG procedure in SAS (23).

To determine if the accumulation of heat was a factor in the appearance of dead spot symptoms, cumulative degree-days (DD) were computed based on $\mathrm{AT}_{\text {Mean }}$ and $\mathrm{ST}_{\text {Mean }}$. Accumulation of DD began on 1 May of each year and was calculated by the following equation:

$$
\mathrm{DD}=\sum^{n}\left[T_{(s \text { or } a)}\right]-\left[T_{b}\right]
$$

where $T_{(s \text { or } a)}$ is the mean daily soil $(s)$ or air ( $a$ ) temperature; $T_{b}$ is the base temperature, and $n$ is the number of days elapsed since 1 May (22). A base temperature $\left(T_{b}\right)$ of $15^{\circ} \mathrm{C}$ was utilized for reasons described below.

Field ascospore release and dead spot symptoms. The release of ascospores and the subsequent development of dead spot infection centers under field conditions were monitored in 2001 and 2002 on the aforementioned putting green. Ascospore release was monitored using a 7-day recording volumetric spore sampler (Burkard Manufacturing Co. Ltd., Rickmansworth, Hertfordshire, UK). The Burkard trap samples $0.6 \mathrm{~m}^{3}$ air $\mathrm{h}^{-1}$ through an orifice $(14 \times 2 \mathrm{~mm})$ located $45 \mathrm{~cm}$ above the ground. Ascospores in the sampled air were trapped on melinax tape, which had been coated with a silicone (high vacuum grease, Dow Corning) and hexane mixture (5:1 wt/vol) that remained tacky, but did not become too viscous during the heat of the summer (18). Hourly ascospore release was determined as described by the manufacturer. Briefly, the tape rotates at a rate of $2 \mathrm{~mm} \mathrm{~h}^{-1}$; therefore, each $2 \times 14 \mathrm{~mm}$ section of tape represents $1 \mathrm{~h}$ of spore collection. Because the orifice is $2 \mathrm{~mm}$ wide, the total number of ascospores captured within any given hour may have been deposited during a 2-h period (4-mm section). Ascospore release was determined by counting all spores deposited within a $100 \mu \mathrm{m} \times 14 \mathrm{~mm}$ traverse. Spores counted along the traverse represent $1 / 20$ th of the total spores estimated for the hour; therefore, data were transformed (ascospores $x$ 20) according to the manufacturers recommended estimation process. Field release of ascospores was monitored hourly between 10 June and 31 October 2001 and 14 May and 31 October 2002.

To determine seasonal patterns or cadences in ascospore release for each year, the numbers of ascospores released and infection centers appearing each day were analyzed utilizing a nonparametric method (LOESS) for estimating regression surfaces $(2,3)$. The LOESS procedure in SAS makes statistical inferences, but does not make assumptions about the parametric form of the regression surface (23). The fraction of the data (i.e., smoothing parameter) in each local neighborhood controls the smoothness of the estimated surface (23). Based on plots of the residuals, a smoothing parameter of 0.06 was selected for daily ascospore release and the number of new infection centers appearing in 2001 and 2002.

\section{RESULTS}

Field observations. In 2000, dead spot symptoms first appeared on 7 June in spots inoculated the previous October (Fig. 1A). Mature pseudothecia were observed embedded in inoculum within diseased spots, but pseudothecia were not observed within diseased bentgrass tissue until 15 June. An increase in the number of infection centers

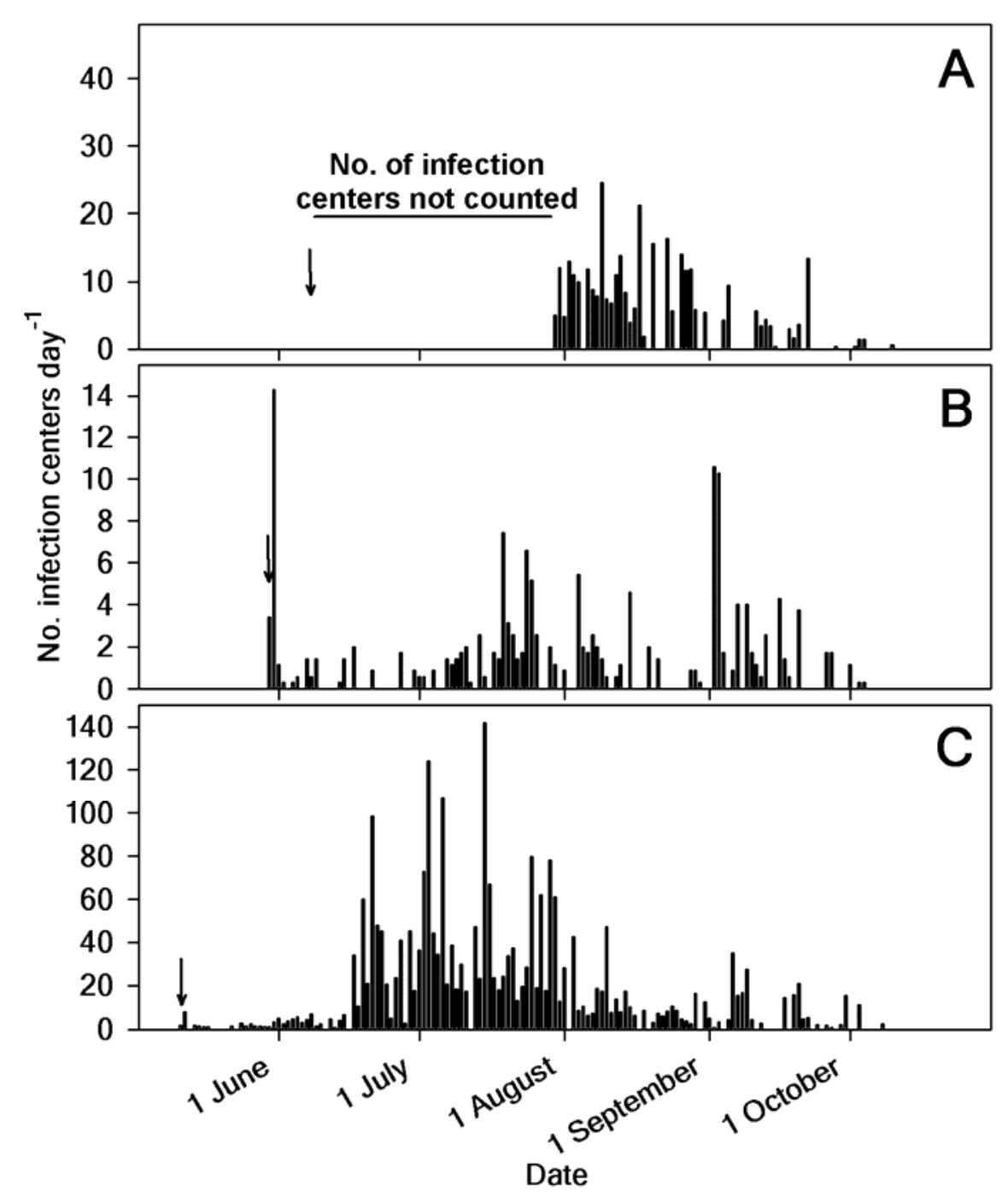

Fig. 1. Daily number of new Ophiosphaerella agrostis infection centers per $93 \mathrm{~m}^{2}$ between 2000 and 2002 on a creeping bentgrass putting green in College Park, MD. Infection centers were counted daily between 30 July and 31 October 2000 (A) and 1 May and 31 October in 2001 (B) and 2002 (C). Arrows indicate date on which initial infection centers appeared each year. was noted on 19 June and again on 4 July, and new spots generally appeared in the areas immediately surrounding the initial dead spots. $O$. agrostis infection centers continued to appear throughout the summer. Disease intensity, based on the number of infection centers, was considered severe in 2000. Between 30 July and 31 October, a total of 332 new $O$. agrostis $\mathrm{IC}_{\text {Total }}$ were observed (Fig. 1A). The maximum number of new infection centers on a single day (9 August) was 25 , and no new infection centers appeared after 10 October.

The area used to monitor dead spot in 2001 was inoculated on 12 March 2001. Although no disease symptoms were present, the pathogen was isolated from root and crown tissue of plants adjacent to the symptoms appeared on 30 May 2001 (Fig. 1B). Pseudothecia first were observed within or on infected creeping bentgrass tissue on 4 June. Not including initial symptoms developing within inoculated inoculum on 12 April. Initial disease 
spots on 30 and 31 May (14 $\left.\mathrm{IC}_{\text {Total }}\right)$, the maximum number of $\mathrm{IC}_{\text {Total }}$ occurring in a single day (2 September) was 11. Disease pressure was very low in 2001, and a total of only $161 \mathrm{IC}_{\text {Total }}$ were observed. Despite this reduction in disease, small numbers $\left(\bar{X} \leq 4.3 \mathrm{IC}_{\text {Total }}\right.$ day $\left.^{-1}\right)$ of new infection centers continued to appear until 4 October.

The study area used to monitor dead spot in 2002 was fumigated the previous August. The area was inoculated on 21 March 2002, and dead spot symptoms first were observed on 11 May 2002 (Fig. 1C). Relatively few new infection centers appeared between 11 May and 15 June (87 $\mathrm{IC}_{\text {Total }}$; however, a dramatic increase in the number of infection centers occurred between mid-June and mid-August. In 2002, disease was extremely severe, and total dead spot infections for May, June, July,
August, September, and October averaged 32, 528, 1,349, 342, 197, and $14 \mathrm{IC}_{\text {Total, }}$, respectively. The maximum number of infection centers observed on a single day was $142 \mathrm{IC}_{\text {Total }}$ and occurred on 15 July. As in the two previous years, no new $O$. agrostis infection centers appeared after early October.

Dead spot predictive model. Development of a descriptive model was attempted from environmental and disease data collected between 2000 and 2002. Correlation analyses among the 20 environmental variables revealed several variables that were highly intercorrelated (i.e., condition of multicollinearity) (data not shown). High correlation coefficients were observed between RAIN and RAIN48 $(r=0.75)$; $\mathrm{SOL}_{\text {Mean }}$ and $\mathrm{SOL}_{\text {Max }}(r=0.93)$; and $\mathrm{WS}_{\text {Mean }}$ and $\mathrm{WS}_{\mathrm{Max}}(r=0.70)$. Correlations among all RH factors (RH90, RH75, RH60, $\mathrm{RH}_{\text {Mean }}, \mathrm{RH}_{\text {Min }}$, $\mathrm{RH} 48_{\text {Mean }}$, and $\mathrm{RH} 72_{\text {Mean }}$ ) also were high and ranged from $r=0.65$ to 0.94 . Similarly, mean, max, and min AT and ST measurements were highly correlated $(r \geq 0.73)$. Lower correlation coefficients were observed among all $\mathrm{RH}$ variables versus LWD ( $r=0.43$ to 0.63 ) and both SOL variables $(r=-0.41$ to $-0.65)$.

Correlation analyses also were performed between each of the environmental variables and infection center data (data not shown). The aforementioned disease variables were most correlated $(P<0.001)$ with all temperature measurements including min, mean, and max AT and ST. Correlation coefficients for these environmental variables and $\mathrm{IC}_{\text {Any }}$ ranged from $r=0.49$ to 0.60 . When compared to $\mathrm{IC}_{\text {Total }}$ and $\mathrm{IC}_{\text {Major }}$,
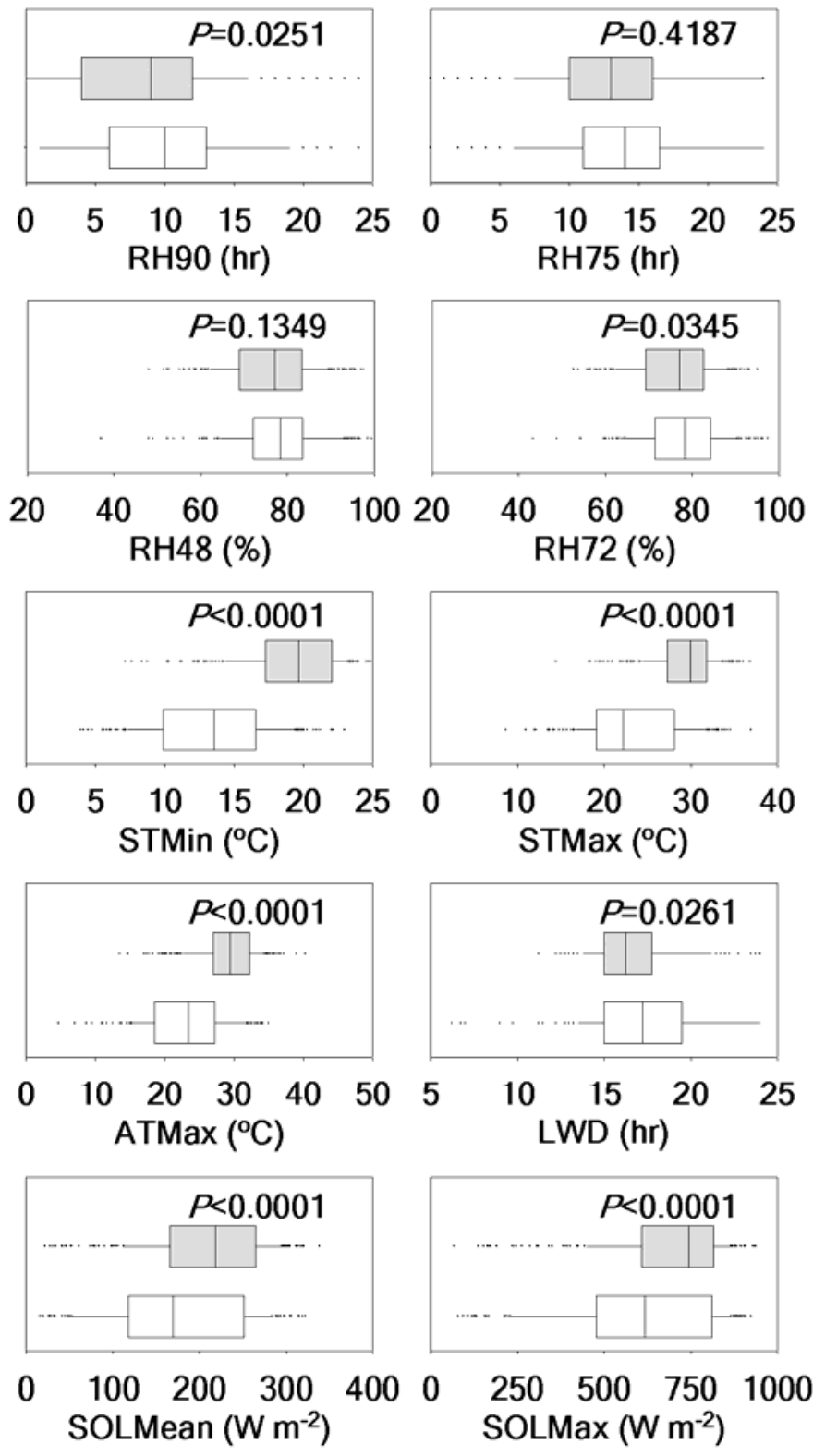

Fig. 2. Distributions of environmental variables on days in which Ophiosphaerella agrostis infection events appeared (gray box) and days in which no new symptoms were observed (white box). Data represent 10\% (left solid line), 25\% (left side of box), 50\% (center line), 75\% (right side of box), and 90\% (right solid line) of the observations recorded between May and October of 2000 to 2002 . Extreme measurements or outliers are indicated by dots. Distributions for each environmental variable were significantly different at the $5 \%$ level where $P<0.0025$. 
correlation coefficients were considerably weaker and ranged from $r=0.25$ to 0.36 and 0.23 to 0.33 , respectively. Additionally, weak correlations were observed between all disease variables and $\mathrm{SOL}_{\text {Mean }}(r$ $=0.15$ to 0.22$), \mathrm{SOL}_{\mathrm{Max}}(r=0.13$ to 0.23$)$, LWD ( $r=-0.11$ to -0.19$)$, and RH90 ( $r=$ -0.11 to -0.19$)$.

The distributions of environmental variables were plotted for days with and days without the appearance of new infection centers $\left(\mathrm{IC}_{\text {Any }}\right)$ (Fig. 2). Additionally, similar distributions were determined using only those days on which major infection events were observed ( $\mathrm{IC}_{\text {Major }}$ ) (Fig. 3). Using the Bonferroni correction, the statistical separations of the aforementioned variables were significant at $P \leq 0.0025$. Distribution data for the 20 variables and $\mathrm{IC}_{\text {Any }}$ revealed several statistical separa- tions including min, mean, and max AT

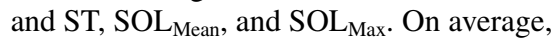
$\operatorname{AT}_{\text {Mean }}\left(\bar{X}=23.7^{\circ} \mathrm{C}\right.$, standard deviation $[\mathrm{SD}]=4.3)$ and $\mathrm{ST}_{\text {Mean }}\left(\bar{X}=24.5^{\circ} \mathrm{C}, \mathrm{SD}=\right.$ 3.2) were higher on days in which dead spot symptoms were observed, when compared to days on which no new infection centers appeared $\left(\mathrm{AT}_{\text {Mean }}: \bar{X}=16.1^{\circ} \mathrm{C}\right.$, $\left.\mathrm{SD}=5.4 ; \mathrm{ST}_{\text {Mean }}: \bar{X}=17.5^{\circ} \mathrm{C}, \mathrm{SD}=4.7\right)$ (Fig. 2). Similarly, average $\mathrm{SOL}_{\mathrm{Mean}}$ and SOL $_{\text {Max }}$ were 34 and $97 \mathrm{~W} \mathrm{~m}^{-2}$ greater on days when new dead spots were observed, when compared to days when none was observed (Fig. 2). Except for $\mathrm{RH}_{\text {Min }}$, all RH variables (RH90, RH75, RH60, $\mathrm{RH}_{\text {Mean }}, \mathrm{RH} 48$, and $\mathrm{RH} 72$ ) were significantly different for $\mathrm{IC}_{\text {Major }}$, indicating an increase in dead spot symptoms on days with extended periods of low RH (Fig. 3). The average daily $\mathrm{RH}_{\text {Mean }}$ was $9 \%$ lower for days with $\geq 20 \mathrm{IC}_{\text {Total }}(\bar{X}=69 \%, \mathrm{SD}=$ 10) than on days with $<20 \operatorname{IC}_{\text {Total }}(\bar{X}=$ $78 \%, \mathrm{SD}=12$ ) (Fig. 3). Moreover, all temperature and $\mathrm{RH}$ variables, LWD and SOL $_{\text {Mean }}$ exhibited distinct statistical separations relative to $\mathrm{IC}_{\text {Major }}$ (Fig. 3). On average, days in which $\geq 20 \mathrm{IC}_{\text {Total }}$ appeared had approximately $2 \mathrm{~h}$ less LWD and $40 \mathrm{~W}$ $\mathrm{m}^{-2}$ greater $\mathrm{SOL}_{\text {Mean }}$, when compared to days in which $<20$ IC $_{\text {Total }}$ were observed.

Based on the correlation coefficients and the examination of statistical distributions and environmental data, it was apparent that the development of dead spot infection centers was influenced by a combination of environmental variables. While AT and ST were most related to dead spot incidence, a combination of low RH, shortened periods of leaf wetness, and high levels of solar radiation $\left(\mathrm{SOL}_{\mathrm{Mean}}\right.$ and

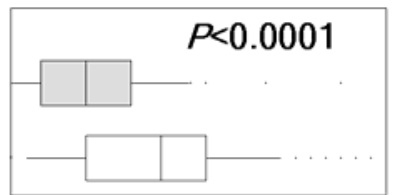

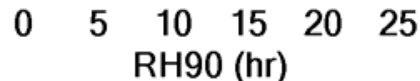
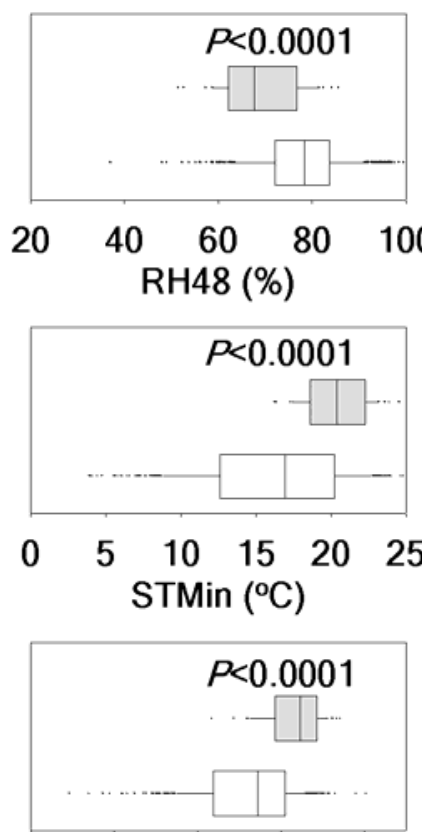

0

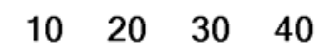
ATMax $\left({ }^{\circ} \mathrm{C}\right)$

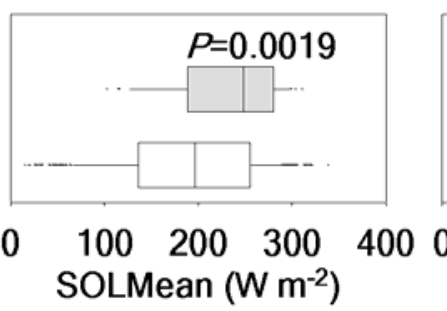

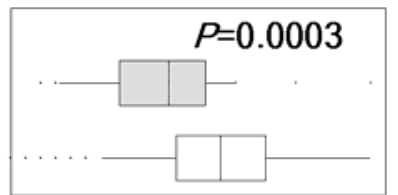

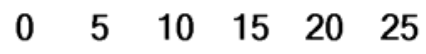

$\mathrm{RH} 75$ (hr)

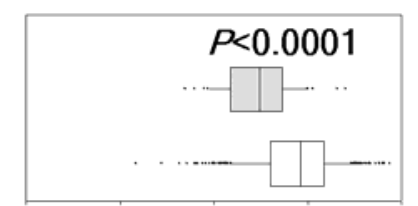

0020

$\begin{array}{llll}40 & 60 & 80 & 100\end{array}$ $\mathrm{RH} 72$ (\%)

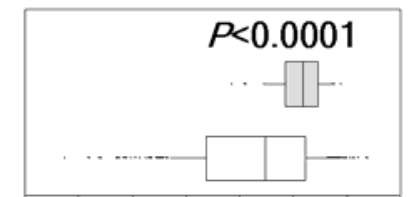

$5 \quad 10152025303540$ STMax $\left({ }^{\circ} \mathrm{C}\right)$
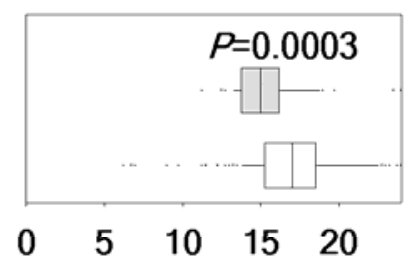

LWD (hr)

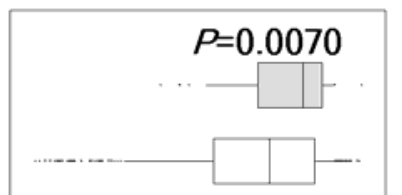

$250 \quad 500 \quad 750$ SOLMax $\left(\mathrm{W} \mathrm{m}^{-2}\right)$

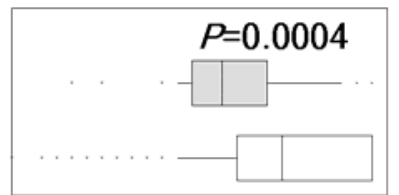

$\begin{array}{lllllll}0 & 5 & 10 & 15 & 20 & 25 & 20\end{array}$ $\mathrm{RH} 60$ (hr)
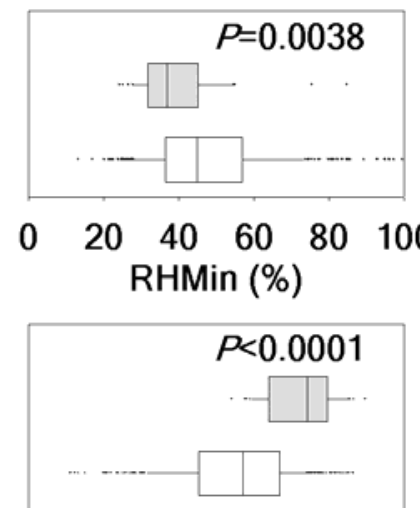

$\begin{array}{lllllll}0 & 5 & 10 & 152025 & 3035\end{array}$ ATMean $\left({ }^{\circ} \mathrm{C}\right)$

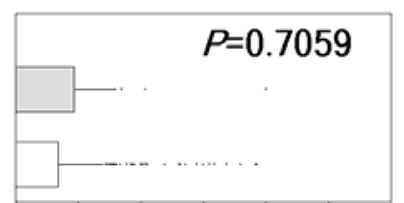

$\begin{array}{lllllll}0 & 10 & 20 & 30 & 40 & 50 & 60\end{array}$ Rain (mm)

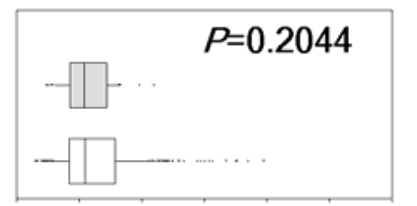

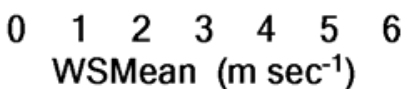
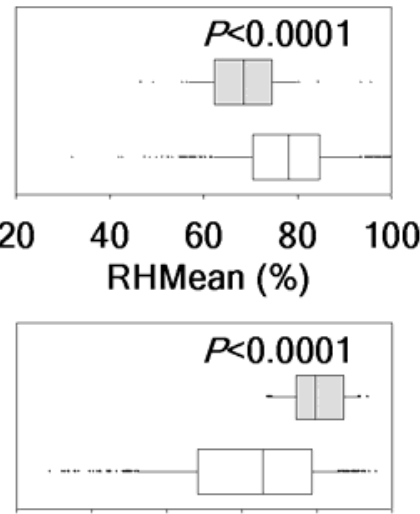

$\begin{array}{llllll}5 & 10 & 15 & 20 & 25 & 30\end{array}$ STMean $\left({ }^{\circ} \mathrm{C}\right)$

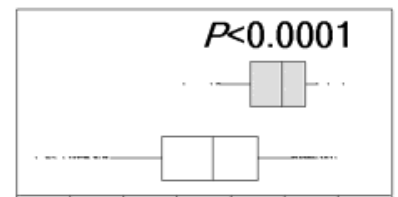

51015202530 ATMin $\left({ }^{\circ} \mathrm{C}\right)$
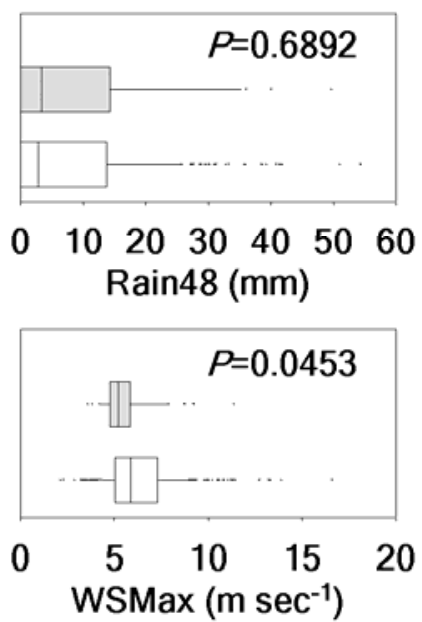

Fig. 3. Distributions of environmental variables on days in which major ( $\geq 20$ dead spots $93 \mathrm{~m}^{-2}$ ) Ophiosphaerella agrostis infection events appeared (gray box) and days in which no major infection events were observed (white box). Data represent 10\% (left solid line), 25\% (left side of box), 50\% (center line), $75 \%$ (right side of box), and 90\% (right solid line) of the observations recorded between May and October of 2000 to 2002 . Extreme measurements or outliers are indicated by dots. The distributions for each environmental variable were significantly different at the $5 \%$ level where $P<0.0025$. 
$\mathrm{SOL}_{\mathrm{Max}}$ ) likely contribute most to the appearance of dead spot symptoms. An EFI was developed to summarize the influence of the aforementioned environmental variables on the appearance and severity of dead spot in creeping bentgrass and to elucidate critical periods for dead spot epidemics.

To develop the EFI, important environmental variables identified previously were selected and point values assigned to each variable based on its importance in predicting the appearance $\left(\mathrm{IC}_{\mathrm{Any}}\right)$ and severity $\left(\mathrm{IC}_{\text {Major }}\right)$ of dead spot symptoms. The use of point values for developing plant disease prediction models was reviewed previously $(10,20)$. The environmental variables selected for the development of each EFI included min, mean, and max AT and ST, RH48, RH72, RH90, RH75, RH60, LWD, SOL Mean $_{\text {, and SOL }}$ Max. Point values for each environmental variable included those that provided the largest $\chi^{2}$ value for the EFI model.

Dead spot severity was considered low and no major infection events occurred in 2001. Therefore, environmental data from 2000 and 2002 were used to develop an EFI for severe epidemics $\left(\mathrm{EFI}_{\text {Major }}\right)$. The $\mathrm{EFI}_{\text {Major }}$ model resulted in a $\chi^{2}$ value of 54 $(P<0.001)$ and included the variables $\mathrm{ST}_{\text {Mean }}, \mathrm{AT}_{\text {Max }}, \mathrm{SOL}_{\text {Mean }}, \mathrm{RH}_{\text {Mean }}$, and LWD (Table 1). An $\mathrm{EFI}_{\text {Major }} \geq 4$ was the best indicator for the appearance of $\geq 20 \mathrm{IC}_{\text {Total }}$ day $^{-1}$. When $\mathrm{EFI}_{\text {Major }}$ was limited to higher (e.g., $\mathrm{EFI}_{\text {Major }} \geq 5$ ) or included lower (e.g., $\mathrm{EFI}_{\text {Major }} \geq 3$ ) accumulated point values, it was more likely to give a false prediction due to under- or over-estimation of days on which $\geq 20 \quad \mathrm{IC}_{\text {Total }}$ appeared, respectively. The aforementioned model accurately

Table 1. Variables and point values used to calculate an environmental favorability index $\left(\mathrm{EFI}_{\text {Major }}\right)$ to provide a warning model for days on which $\geq 20$ dead spot infection centers per 93 $\mathrm{m}^{2}$ appear in creeping bentgrass

\begin{tabular}{|c|c|c|}
\hline $\begin{array}{l}\text { Environmental } \\
\text { variable }^{\mathrm{y}}\end{array}$ & Condition & $\begin{array}{l}\text { Point } \\
\text { value }^{z}\end{array}$ \\
\hline $\mathrm{ST}_{\text {Mean }}$ & $\begin{array}{l}<18^{\circ} \mathrm{C} \\
18-24^{\circ} \mathrm{C} \\
>24^{\circ} \mathrm{C}\end{array}$ & $\begin{array}{l}0 \\
1 \\
2\end{array}$ \\
\hline $\mathrm{AT}_{\mathrm{Max}}$ & $\begin{array}{l}<27^{\circ} \mathrm{C} \\
\geq 27^{\circ} \mathrm{C}\end{array}$ & $\begin{array}{l}0 \\
1\end{array}$ \\
\hline $\mathrm{RH}_{\text {Mean }}$ & $\begin{array}{l}>80 \% \\
\leq 80 \%\end{array}$ & $\begin{array}{l}0 \\
1\end{array}$ \\
\hline $\mathrm{SOL}_{\text {Mean }}$ & $\begin{array}{l}<230 \mathrm{~W} \mathrm{~m}^{-2} \\
\geq 230 \mathrm{~W} \mathrm{~m}^{-2}\end{array}$ & $\begin{array}{l}0 \\
1\end{array}$ \\
\hline LWD & $\begin{array}{l}>14 \mathrm{~h} \\
\leq 14 \mathrm{~h}\end{array}$ & $\begin{array}{l}0 \\
1\end{array}$ \\
\hline
\end{tabular}

y Variables were measured during a 24-h period prior to 0800 hours for all days where: $\mathrm{ST}_{\text {Mean }}$ $=$ mean soil temperature $\left({ }^{\circ} \mathrm{C}\right) ; \mathrm{AT}_{\text {Mean }}=$ mean air temperature $\left({ }^{\circ} \mathrm{C}\right) ; \mathrm{RH}_{\text {Mean }}=$ mean relative humidity $(\%)$; $\mathrm{SOL}_{\text {Mean }}=$ mean solar irradiance $\left(\mathrm{W} \mathrm{m}^{-2}\right)$; and LWD = leaf wetness duration (hours).

${ }^{\mathrm{z}}$ Point values were added to calculate the environmental favorability index. predicted $\mathrm{IC}_{\text {Major }}$ (i.e., "yes" or "no" events) on 176 of 238 days (74\%) in 2000 and 2002 (Table 2). The $\mathrm{EFI}_{\text {Major }}$ accurately predicted the appearance of major dead spot infection epidemics on 37 of 40 days (93\%).

Although five variables were used to determine the initial model ( $\mathrm{EFI}_{\text {Major }}$ ), a simplified EFI (EFI Simplified $)$ was developed using stepwise regression. Stepwise regression analysis was performed on the environmental data used to develop the predicted values of $\mathrm{EFI}_{\text {Major }}$. The environmental variables that provided the simplest and best-fit model included $\mathrm{RH}_{\text {Mean }}$ and $\mathrm{AT}_{\mathrm{Max}}$ and resulted in the equation: $\mathrm{EFI}_{\text {Sim- }}$ plified $=9.68 \times 10^{-3} T^{2}-0.31 T-3.79 \times 10^{-6}$ $\mathrm{RH}^{3}-1.11 \times 10^{-3} \mathrm{TRH}-1.83 \times 0^{-4} \mathrm{~T}^{2} \mathrm{RH}-$ $4.46 \times 10^{-6} T^{3} \mathrm{RH}$, where $\mathrm{EFI}_{\text {Simplified }}$ is the two-parameter environmental favorability index, $T$ is the maximum daily AT $\left({ }^{\circ} \mathrm{C}\right)$, and $\mathrm{RH}$ is the mean daily $\mathrm{RH}(\%)$. The model had an adjusted $R^{2}=0.80$, and all estimated coefficients were significant $(P$ $<0.001)$. A comparison between the twovariable ( $\left.\mathrm{EFI}_{\text {Simplified }}\right)$ and the five-variable $\left(\mathrm{EFI}_{\mathrm{Major}}\right)$ models, however, revealed a reduction in the number of correct predictions of dead spot epidemics from the $\mathrm{EFI}_{\text {Simplified }}$ model. The model $\mathrm{EFI}_{\text {Simplified }}$ only predicted 26 of 40 days on which $\geq 20$ $\mathrm{IC}_{\text {Total }}$ day $^{-1}$ appeared; a reduction from 93 to $65 \%$ accuracy. The five-variable EFI model provided a higher accuracy with regards to predicting major dead spot events. Comparable disease warnings, however, were not achieved with fewer environmental inputs.

An EFI that could predict the appearance of a single infection center ( IC $_{\text {Any }}$ ) also was developed. The most accurate EFI model for predicting the appearance of dead spot symptoms $\left(\mathrm{EFI}_{\mathrm{Any}}\right)$ included the variables $\mathrm{ST}_{\text {Mean }}, \mathrm{AT}_{\text {Mean }}, \mathrm{AT}_{\mathrm{Min}}, \mathrm{SOL}_{\mathrm{Max}}$,

Table 2. Chi-square $\left(\chi^{2}\right)$ analyses of individual and combined environmental variables used to predict the appearance of dead spot infection centers $\left(\mathrm{IC}_{\mathrm{Any}}\right.$ ) or dead spot infection centers $\geq 20$ per $93 \mathrm{~m}^{-2}$ $\left(\mathrm{IC}_{\text {Major }}\right)$

\begin{tabular}{lrrc}
\hline Disease parameter(s) & Yes & No & $\chi^{\mathbf{2}}$ (accuracy) $^{\mathbf{y}}$ \\
\hline $\mathrm{IC}_{\text {Any }}$ & 204 & & \\
$\mathrm{ST}_{\text {Mean }} \geq 20^{\circ} \mathrm{C}$ & 30 & 50 & 135 \\
$\mathrm{ST}_{\text {Mean }}<20^{\circ} \mathrm{C}$ & 204 & 115 & $(80 \%)$ \\
$\mathrm{AT}_{\text {Mean }} \geq 18^{\circ} \mathrm{C}$ & 27 & 61 & 113 \\
$\mathrm{AT}_{\text {Mean }}<18^{\circ} \mathrm{C}$ & 214 & 102 & $(77 \%)$ \\
$\mathrm{AT}_{\text {Min }} \geq 10^{\circ} \mathrm{C}$ & 18 & 81 & 92 \\
$\mathrm{AT}_{\text {Min }}<10^{\circ} \mathrm{C}$ & 208 & 82 & $(75 \%)$ \\
$\mathrm{AT}_{\text {Max }} \geq 23^{\circ} \mathrm{C}$ & 24 & 84 & 72 \\
$\mathrm{AT}_{\text {Max }}<23^{\circ} \mathrm{C}$ & 206 & 79 & $(73 \%)$ \\
$\mathrm{EFI}_{\text {Any }} \geq 4^{\mathrm{z}}$ & 20 & 63 & 120 \\
$\mathrm{EFI}_{\text {Any }}<4$ & & 98 & $(79 \%)$ \\
$\mathrm{IC}_{\text {Major }}$ & 37 & & \\
$\mathrm{EFI}_{\text {Major }} \geq 4^{\mathrm{z}}$ & 3 & 59 & $(74 \%)$ \\
$\mathrm{EFI}_{\text {Major }}<4$ & 139 & \\
\hline
\end{tabular}

${ }^{x}$ All values are significant $(P<0.001)$ according to the Pearson chi-square test.

y Accuracy (\%) represents the number of correct predictions for days in which $\mathrm{IC}_{\text {Any }}$ or $\mathrm{IC}_{\text {Major }}=$ "Yes" or "No", averaged over all dates.

${ }^{\mathrm{z}}$ Environmental parameters and their corresponding point values included in the environmental favorability index models $\mathrm{EFI}_{\mathrm{Major}}$ and $\mathrm{EFI}_{\mathrm{Any}}$ are shown in Tables 1 and 3, respectively. 
Table 3. Variables and point values used to calculate an environmental favorability index $\left(\mathrm{EFI}_{\text {Any }}\right)$ to provide a warning model for dead spot symptom expression in creeping bentgrass

\begin{tabular}{|c|c|c|}
\hline $\begin{array}{l}\text { Environmental } \\
\text { variable }^{\mathrm{y}}\end{array}$ & Condition & $\begin{array}{l}\text { Point } \\
\text { value }^{\mathrm{z}}\end{array}$ \\
\hline $\mathrm{ST}_{\text {Mean }}$ & $\begin{array}{l}<15^{\circ} \mathrm{C} \\
15-20^{\circ} \mathrm{C} \\
>20^{\circ} \mathrm{C}\end{array}$ & $\begin{array}{l}0 \\
1 \\
2\end{array}$ \\
\hline $\mathrm{AT}_{\text {Mean }}$ & $\begin{array}{l}<18^{\circ} \mathrm{C} \\
\geq 18^{\circ} \mathrm{C}\end{array}$ & $\begin{array}{l}0 \\
1\end{array}$ \\
\hline $\mathrm{AT}_{\text {Min }}$ & $\begin{array}{l}<10^{\circ} \mathrm{C} \\
\geq 10^{\circ} \mathrm{C}\end{array}$ & $\begin{array}{l}0 \\
1\end{array}$ \\
\hline $\mathrm{SOL}_{\mathrm{Max}}$ & $\begin{array}{l}<580 \mathrm{~W} \mathrm{~m}^{-2} \\
\geq 580 \mathrm{~W} \mathrm{~m}^{-2}\end{array}$ & $\begin{array}{l}0 \\
1\end{array}$ \\
\hline LWD & $\begin{array}{l}>18 \mathrm{~h} \\
\leq 18 \mathrm{~h}\end{array}$ & $\begin{array}{l}0 \\
1\end{array}$ \\
\hline
\end{tabular}

y Variables were measured during a 24-h period prior to 0800 hours for all days where: $\mathrm{ST}_{\text {Mean }}=$ mean soil temperature $\left({ }^{\circ} \mathrm{C}\right) ; \mathrm{AT}_{\text {Mean }}=$ mean air temperature $\left({ }^{\circ} \mathrm{C}\right) ; \mathrm{AT}_{\mathrm{Min}}=$ minimum air temperature $\left({ }^{\circ} \mathrm{C}\right)$; $\mathrm{SOL}_{\mathrm{Max}}=$ maximum solar irradiance $\left(\mathrm{W} \mathrm{m} \mathrm{m}^{-2}\right)$; and LWD = leaf wetness duration (hours).

${ }^{\mathrm{z}}$ Point values were added to calculate the environmental favorability index.

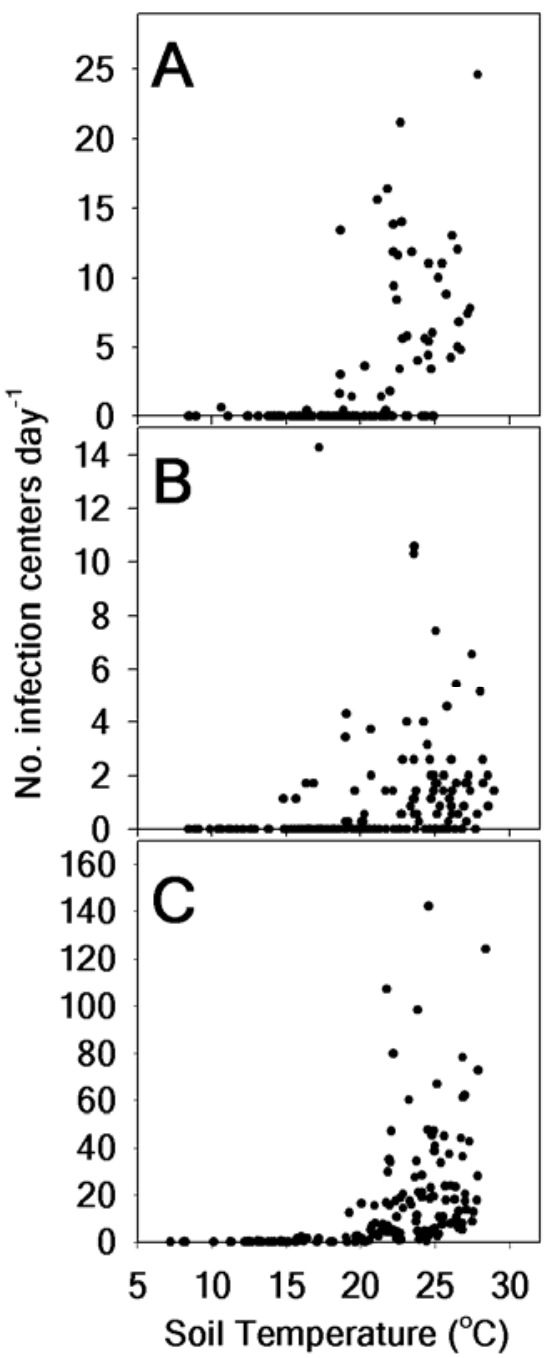

Fig. 4. Relationship between daily mean soil temperature and the number of new dead spot infection centers appearing daily per $93 \mathrm{~m}^{2}$, 2000 to 2002.
Seasonal ascospore release and dead spot symptom development. Based on a visual examination of daily release of ascospore data over the course of a season in 2001 and 2002, it was apparent that $O$. agrostis ascospores were released in a cyclical fashion. To investigate this pattern, data were subjected to nonparametric sta-

Table 4. Accumulated degree days (DD) based on soil (ST) and air (AT) temperatures from 1 May until the day of primary dead spot symptom expression for 3 years

\begin{tabular}{lcc}
\hline & \multicolumn{2}{c}{ Primary symptoms $^{\mathbf{z}}$} \\
\cline { 2 - 3 } Year & DD $_{\text {ST }}$ & DD $_{\text {AT }}$ \\
\hline 2000 & 199 & 157 \\
2001 & 125 & 66 \\
2002 & 31 & 24 \\
\hline
\end{tabular}

${ }^{\mathrm{z}}$ Primary symptoms indicate days in which new infection centers were first observed on 7 June 2000, 30 May 2001, and 11 May 2002. tistical smoothing using the LOESS procedure in SAS (23). Field data collected in 2001 and 2002 were square root transformed and analyzed separately.

In 2001, the 13 estimated peak periods associated with the release of ascospores occurred on 16 and 30 June, 12, 17, and 27 July, 14, 22, and 30 August, 13, 21, and 30 September, and 16 and 26 October 2001 (Fig. 5C). The average number of days between each estimated peak in ascospore release was $11 \pm 1.1$ days (standard error) in 2001. The number of infection centers appearing in 2001 was low, and the magnitude of each daily count was small (Fig. 5). Regardless, 10 estimated peaks in the number of new dead spot infection centers that appeared each day occurred every $12 \pm 1$ days between 31 May and 18 September. Peaks in new infection centers occurring on 31 May and 8 June 2001 appeared

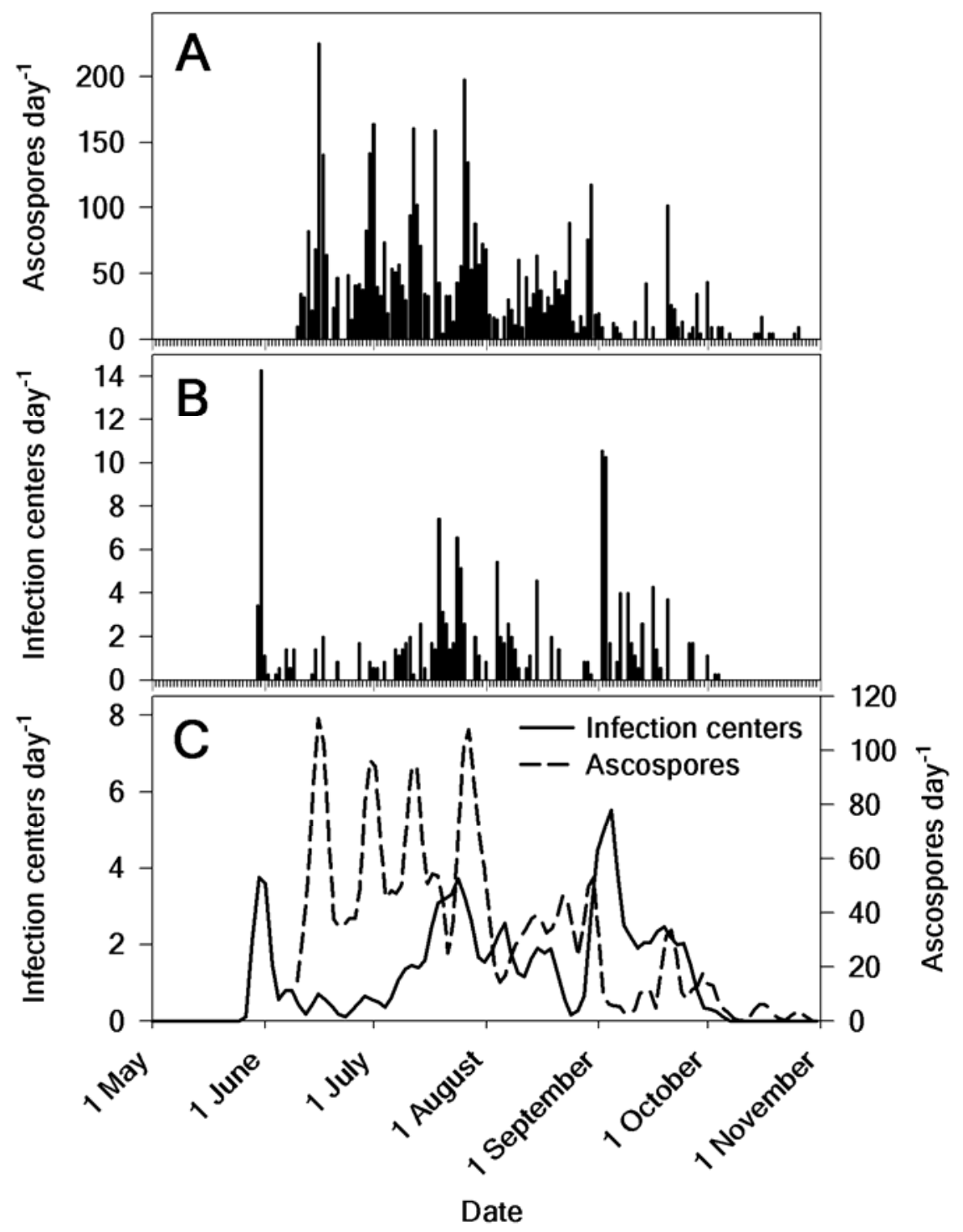

Fig. 5. Seasonal relationship between the daily release of ascospores (A) and the appearance of new Ophiosphaerella agrostis infection centers per $93 \mathrm{~m}^{2}$ (B), 2001. New infection centers (B) were counted daily between 1 May and 31 October and ascospores (A) were collected between 10 June and 31 October 2001. Estimated curves (C) were fitted using a nonparametric, locally weighted regression analysis (Proc Loess). 
prior to the placement of the volumetric spore trap in the field. Ascospores released around 30 June and 12,18, and 26 July were followed by an increase in new infection centers on 12 (12 days after release [DAR]), 19 (7 DAR), and 24 (6 DAR) July, and 4 (9 DAR) August, respectively. Finally, the increase in the number of infection centers occurring in early September was preceded by three ascospore release events on 15,24, and 30 August.

A total of 13 estimated ascospore release events were observed in 2002 (Fig. $6 \mathrm{C})$. The first 3 estimated release events likely were the result of ascospores originating from pseudothecia that had developed within or on the inoculum. The remaining 10 estimated ascospore release events peaked on 15 and 29 June, 11, 17, and 23 July, 6 and 27 August, 12 and 24 September, and 10 October 2002.
The average number of days between estimated peaks in ascospore release was $12 \pm 1.3$ days in 2002. Unlike in 2001, dead spot was severe in 2002. Estimated periods associated with the daily appearance of infection centers peaked on 21 June, 4, 15, and 28 July, 10 and $28 \mathrm{Au}-$ gust, and 7, 19, and 30 September 2002. On average, each peak in the appearance of new infection centers occurred every $13 \pm 0.9$ days. Throughout 2002, most infection centers (82\%) appeared between 17 June and 10 August. During this period, each peak in the estimated number of infection centers was preceded ( 3 to 6 days) by a peak in ascospore release. The remaining number of new infection centers peaked 3 to 10 days after spore release. Despite a large number of ascospores collected in late August, new infection centers appearing thereafter were relatively few in number.

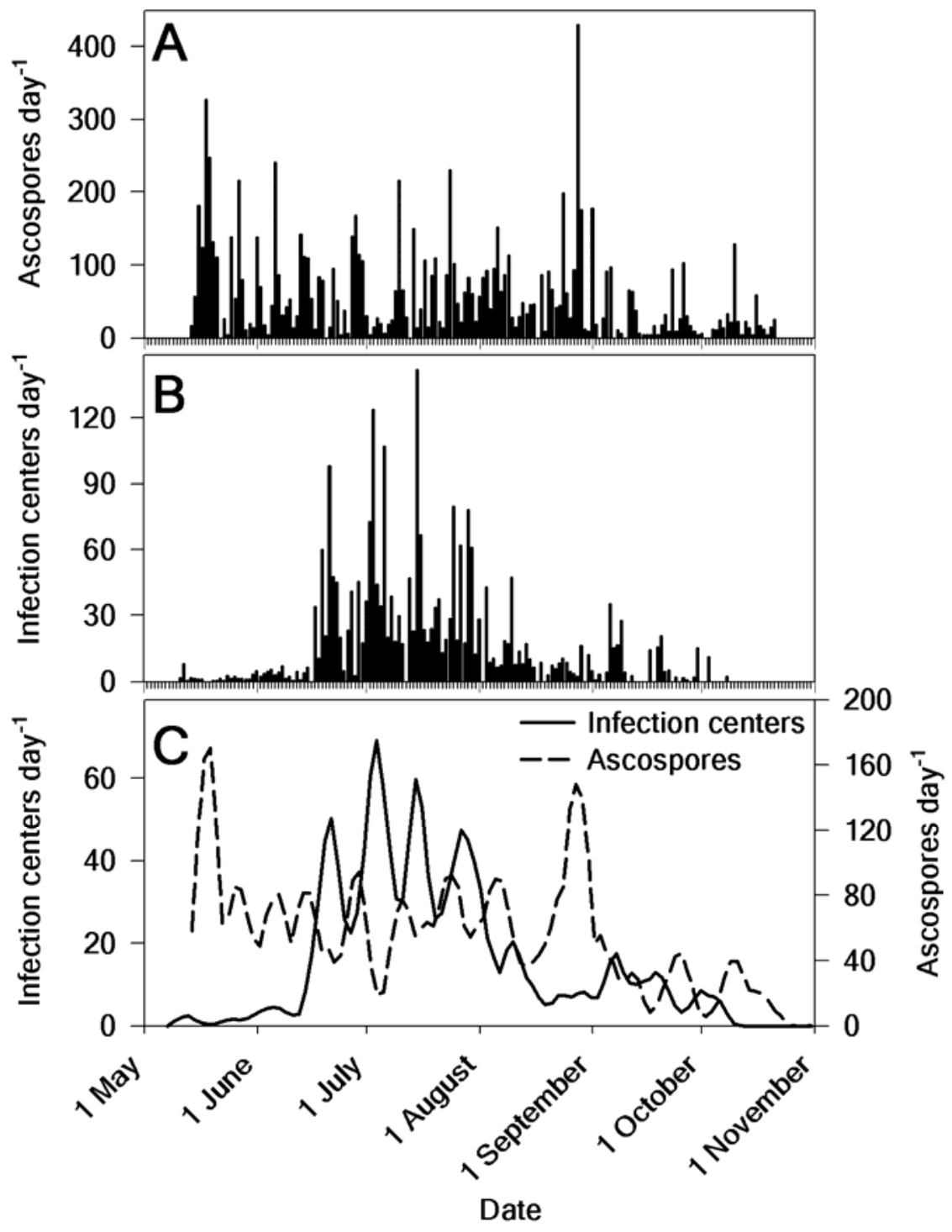

Fig. 6. Seasonal relationship between the daily release of ascospores (A) and the appearance of new Ophiosphaerella agrostis infection centers per $93 \mathrm{~m}^{2}(\mathbf{B}), 2002$. New infection centers (B) were counted daily between 1 May and 31 October and ascospores (A) were collected between 14 May and 31 October 2002. Estimated curves (C) were fitted using a nonparametric, locally weighted regression analysis (Proc Loess).

\section{DISCUSSION}

Except for the DD model, the environmental models ( $\mathrm{EFI}_{\text {Any }}$ and single-variable) were able to accurately predict ( 73 to $80 \%$ ) the appearance of new dead spot infection centers. The $\mathrm{EFI}_{\text {Major }}$ was accurate $(74 \%)$ in predicting days on which $\geq 20 \quad \mathrm{IC}_{\text {Total }}$ appeared. Environmental factors that were associated with dead spot incidence and/or days with major events included AT, ST, SOL, LWD, and RH. Based on the results of these field studies, dead spot symptom development appears to be most associated with temperature. Daily $\mathrm{ST}_{\text {Mean }} \geq 20^{\circ} \mathrm{C}$ or $\mathrm{AT}_{\text {Mean }} \geq 18^{\circ} \mathrm{C}$ between late spring and late summer were the best single-variable indicators for the appearance of dead spot infection centers. Previous research, however, indicated that reactivation of dead spot symptoms in winter-dormant bentgrass only occurred after incubation for 12 to 28 days at temperatures between 20 and $30^{\circ} \mathrm{C}$ (19). Therefore, although the aforementioned temperatures (i.e., $\mathrm{ST}_{\text {Mean }} \geq$ $20^{\circ} \mathrm{C}$ or $\mathrm{AT}_{\text {Mean }} \geq 18^{\circ} \mathrm{C}$ ) predicted the appearance of dead spot symptoms with 77 to $80 \%$ accuracy, it is likely that an accumulation of heat in the spring is required prior to the development of initial disease symptoms. The single-variable model that used ST of $\geq 20^{\circ} \mathrm{C}$ to predict the appearance of new $O$. agrostis infection centers generally resulted in false predictions during late spring. In the autumn months, however, ST generally declined dramatically $\left(21^{\circ} \mathrm{C}\right.$ in September to $14^{\circ} \mathrm{C}$ in October), and few new infection centers were observed after early October.

The lack of accuracy of the DD model indicated that further study is warranted with respect to the use of DD for predicting the appearance of initial dead spot symptoms. It is unclear if inoculation timings influenced the appearance of initial dead spot symptoms. For 2000, the study area was inoculated in October 1999, but disease symptoms did not appear until 7 June 2000 (DD = 199). For the remaining 2 years, the areas were inoculated on 12 March 2001 and 21 March 2002, and disease symptoms developed in mid- to late-May (DD = 125 in 2001 and DD $=31$ in 2002). Kaminski and Dernoeden (16) found that although the pathogen was capable of overwintering in various bentgrass tissues, recovery of the pathogen generally declined throughout the autumn and winter months. Early disease development in 2001 and 2002 may have been due to the spring inoculation and therefore greater levels of viable inoculum earlier in the year. Due to the early development of dead spot symptoms in 2002, future investigations should begin DD data collection earlier in the season (i.e., $~ 1$ April in Maryland). Plots should be inoculated in autumn rather than spring so that the pathogen can more naturally colonize plants and overwinter. 
Based on the severity model ( $\left.\mathrm{EFI}_{\mathrm{Major}}\right)$, it appears that in addition to elevated temperatures $\left(\mathrm{AT}_{\mathrm{Max}} \geq 27^{\circ} \mathrm{C}\right.$ and $\mathrm{ST}_{\text {Mean }} \geq$ $18^{\circ} \mathrm{C}$ ), several environmental variables contributed to major dead spot epidemics. Days with $\geq 20 \quad \mathrm{IC}_{\text {Total }}$ generally were predicted by a combination of lower $\mathrm{RH}$ $\left(\mathrm{RH}_{\text {Mean }} \leq 80 \%\right)$, fewer hours of leaf wetness (LWD $\leq 14 \mathrm{~h}$ ), and an increase in solar irradiance $\left(\mathrm{SOL}_{\mathrm{Mean}} \geq 230 \mathrm{~W} \mathrm{~m}^{-2}\right)$. These conditions support previous reports in which dead spot was found to be most severe on putting greens exposed to full sun (increased SOL), adequate wind movement (lowered RH), and on mounds or ridges and south-facing slopes that would be more prone to heat and drought stress and reduced leaf wetness periods (14).

In general, ascospore discharge occurred every 11 to 14 days during peak spore release, and infection centers appeared 3 to 10 days later. The influence of temperature likely plays an important role in the infection process by ascospores. Although ascospores were released throughout May 2002, mean air and soil temperatures during the period in which ascospores were released were 10 and $13^{\circ} \mathrm{C}$, respectively. An increase in the number of dead spot infection centers, however, did not occur until mid-June, when both air and soil temperatures averaged $24^{\circ} \mathrm{C}$. Temperatures during the early release events likely were too low for infection to occur. Results from this study indicate that symptom development can occur within a short period (3 to 10 days) following ascospore release. Infection and subsequent symptom expression (i.e., infection centers) likely is influenced most by temperature at the time ascospores alight on moist bentgrass tissues and in the days following infection. Undoubtedly, other factors also are involved in the infection process prior to symptom expression. In the field, foliar mycelium rarely is present on infected tissue, and infections appear to develop as spots or patches. Tracking of the pathogen on equipment or in a pattern consistent with water flow has not been observed. It is not known why individual spots or patches do not increase beyond a few centimeters in diameter.

Due to the pathogen's ability to rapidly produce prodigious numbers of pseudothecia, relatively few infection centers may provide sufficient inoculum to severely impact the playability of affected greens. Therefore, the disease threshold for dead spot is extremely low. Based on results from this and other studies $(13,25)$, preventive fungicide applications may be most efficacious when initiated prior to ST consistently reaching $\geq 15^{\circ} \mathrm{C}$ in late spring and possibly continued until ST drops consistently below $20^{\circ} \mathrm{C}$. It is important to note, however, that new infection centers appearing in September and October generally remain small, and complete recovery from these infection centers likely would be achievable with autumn applications of nitrogen fertilizer (15).

\section{ACKNOWLEDGMENTS}

We are grateful for the financial support provided by the United States Golf Association, and for helpful comments and insights from Arvydas Grybauskas.

\section{LITERATURE CITED}

1. Câmara, M. P. S., O'Neill, N. R., van Berkum, P., Dernoeden, P. H., and Palm, M. E. 2000. Ophiosphaerella agrostis sp. nov. and its relationship to other species of Ophiosphaerella. Mycologia 92:317-325.

2. Cleveland, W. S., Devlin, S. J., and Grosse, E. 1988. Regression by local fitting. J. Econometrics 37:87-114.

3. Cleveland, W. S., and Grosse, E. 1991. Computational methods for local regression. Stat. Comput. 1:47-62.

4. Cody, R. P., and Smith, J. K. 1991. Applied Statistics and the SAS Programming Language. Elsevier Science, New York.

5. Danneberger, T. K., Vargas, J. M., Jr., and Jones, A. L. 1984. A model for weather-based forecasting of anthracnose on annual bluegrass. Phytopathology 74:448-451.

6. Dernoeden, P. H., O'Neill, N. R., Câmara, M. P. S., and Feng, Y. 1999. A new disease of Agrostis palustris incited by an undescribed species of Ophiosphaerella. Plant Dis. 83:397.

7. Draper, N. R., and Smith, H. 1981. Applied Regression Analysis. 2nd ed. John Wiley \& Sons, New York.

8. Fidanza, M. A., Dernoeden, P. H., and Grybauskas, A. P. 1996. Development and field validation of a brown patch warning model for perennial ryegrass turf. Phytopathology 86:385-390.

9. Freund, R. J., and Little, R. C. 1991. SAS System for Regression. 2nd ed. SAS Institute, Cary, NC.

10. Fry, W. E., and Fohner, G. R. 1985. Construction of predictive models: I. Forecasting disease development. Pages 161-178 in: Advances in Plant Pathology: III. Mathematical Modeling of Crop Disease. C. A. Gilligan, ed. Academic Press, New York.

11. Gillespie, T. J., and Kidd, G. E. 1978. Sensing duration of leaf moisture retention using electrical impedance grids. Can. J. Plant Sci. 58:179-187.
12. Hall, R. 1984. Relationship between weather factors and dollar spot of creeping bentgrass. Can. J. Plant Sci. 64:167-174.

13. Kaminski, J. E. 2004. Biology of Ophiosphaerella agrostis, epidemiology of dead spot, and a molecular description of the pathogen. Ph.D. diss. University of Maryland, College Park.

14. Kaminski, J. E., and Dernoeden, P. H. 2002. Geographic distribution, cultivar susceptibility, and field observations on bentgrass dead spot. Plant Dis. 86:1253-1259.

15. Kaminski, J. E., and Dernoeden, P. H. 2005. Nitrogen source impact on dead spot (Ophiosphaerella agrostis) recovery in creeping bentgrass. Int. Turfgrass Soc. Res. J. 10:214223.

16. Kaminski, J. E., and Dernoeden, P. H. 2005. Severity of dead spot, pseudothecia development and overwintering of Ophiosphaerella agrostis in creeping bentgrass. Phytopathology 95:248-254.

17. Kaminski, J. E., Dernoeden, P. H., Mischke, S., and O'Neill, N. R. 2005. Genetic diversity among Ophiosphaerella agrostis strains causing dead spot in creeping bentgrass. Plant Dis. 90:146-154.

18. Kaminski, J. E., Dernoeden, P. H., and O'Neill, N. R. 2005. Environmental influences on the release of Ophiosphaerella agrostis ascospores under controlled and field conditions. Phytopathology 95:1356-1362.

19. Kaminski, J. E., Dernoeden, P. H., O'Neill, N. R., and Momen, B. 2002. Reactivation of bentgrass dead spot and growth, pseudothecia production, and ascospore germination of Ophiosphaerella agrostis. Plant Dis. 86:12901296

20. Krause, R. A., and Massie, L. B. 1975. Predictive systems: Modern approaches to disease control. Annu. Rev. Phytopathol. 13:31-47.

21. Nutter, F. W., Cole, H., and Schein, R. D. 1983. Disease forecasting system for warm weather Pythium blight of turfgrass. Plant Dis. 67:1126-1128.

22. Ritchie, J. T., and NeSmith, D. S. 1991. Temperature and crop development. Pages 5-29 in Modeling Plant and Soil Systems. J. Hanks and J. T. Ritchie, ed. Agron. Monogr. 31. ASA CSSA, and SSSA, Madison, WI.

23. SAS Institute Inc. 2000. SAS OnlineDoc. Version 8, SAS Institute, Cary, NC.

24. Scherm, H., and van Bruggen, A. H. C. 1994 Weather variables associated with infection of lettuce by downy mildew (Bremia lactucae) in coastal California. Phytopathology 84:860865.

25. Towers, G. W., Majumdar, P. R., Weibel, E. N., Frasier, C. L., Vaiciunas, J. N., Peacos, M., and Clarke, B. 2000. Evaluation of chemical and biological fungicides for the control of bentgrass dead spot in creeping bentgrass. Rutgers Turfgrass Proc. 32:211-215.

26. United States Golf Association Green Section Staff. 1993. USGA recommendations for method of putting green construction. USGA Green Sect. Record 31:1-3.

27. Witte, R. S. 1980. Statistics. Holt, Rinehart, and Winston Publishers, New York. 